\title{
Stipular buds in a natural population of Danaea nodosa (Marattiaceae) in gallery forest from Brazilian Savanna ${ }^{1}$
}

\author{
Carlos Rodrigo Lehn ${ }^{2,4}$ \& Frederico Santos Lopes ${ }^{3}$
}

\begin{abstract}
The occurrence of stipular buds is commonly observed in Marattiaceae under controlled conditions. In this study, is described the development of stipular buds in a population of Danaea nodosa located into a gallery forest of the Brazilian savanna. From June 2006 to July 200740 individuals were monitored and 13 of them presented stipular buds. The formation of stipular buds was observed in August and September 2006, a time corresponding to the end of the dry season. In only two individuals, the stipular buds evolved to ramets. An additional survey conducted in April 2008, revealed that the ramets continued to product new leaves. This study provides an important information about the reproductive strategy of the species under natural conditions, which can guide future researches with conservationist purposes to native ferns.
\end{abstract}

Key words: adventicious buds, clonal propagation, ferns, vegetative shoots.

\section{Resumo}

A ocorrência de brotos estipulares em Marattiaceae tem sido observada por diferentes autores, geralmente sob condições de cultivo. Neste estudo, é descrito o desenvolvimento de brotos estipulares em uma população de Danaea nodosa localizada em uma Mata de Galeria no Cerrado brasileiro. De junho de 2006 a julho de 2007, 40 indivíduos foram monitorados e 13 destes apresentaram brotos estipulares. A formação dos brotos estipulares foi observada em agosto e setembro de 2006, período correspondente ao final da estação seca. Em dois destes indivíduos, os brotos estipulares evoluíram para esporófitos jovens. Uma visita adicional realizada em abril de 2008 revelou que estas plântulas continuaram a produzir novas frondes. Este estudo fornece uma importante informação sobre a estratégia de propagação vegetativa da espécie em condições naturais, o que pode orientar novas pesquisas com propósitos conservacionistas para samambaias nativas.

Palavras-chave: brotos adventícios, propagação clonal, samambaias, gemas vegetativas.

Ferns show different forms of reproduction. Young sporophytes can be added to a population from the germination of spores or as ramets (juvenile sporophytes) resulting from vegetative reproduction (Sharpe \& Mehltreter 2010). Among the forms of vegetative reproduction found in ferns, new buds can originate from gametophytes (Sheffield 2008), petioles (MacVeigh 1937; Troop \& Mickel 1968), rhizomatous stolons
(Schmitt \& Windisch 2006), roots (Sharpe \& Mehltreter 2010) and stipular buds (Sharpe \& Jernstedt 1991; Chiou et al. 2006; Huang et al. 2010), among others. It is estimated that the formation of vegetative buds occurs in about $5 \%$ of fern species (Sharpe \& Mehltreter 2010), resulting in meristematic tissue that develops independently at the apex of the rhizome (Sharpe \& Jernstedt 1991).

\footnotetext{
${ }^{1}$ Research conducted as part of Master's Degree of the author at the Post-graduation Program in Plant Biology, Federal University of Mato Grosso do Sul, UFMS.

${ }^{2}$ Instituto Federal Farroupilha, campus Panambi, R. Erechim 860, Bairro Planalto, 98280-000, Panambi, RS, Brasil.

${ }^{3}$ Universidade Federal de Mato Grosso do Sul, Prog. Pós-graduação em Biologia Vegetal, Cidade Universitária s/n, 79070-900, Campo Grande, MS, Brasil.

${ }^{4}$ Author for correspondence: crlehn@gmail.com
} 
Among the families of ferns where vegetative reproduction occurs, Marattiaceae has as a notable characteristic the presence of stipules (Tryon \& Tryon 1982). These stipules are located at the base of each petiole and provide protection during the initial development of the leaves and persist adhered to the rhizome even after the remainder of the leaf has senescenced and abscised. These structures show primary meristematic tissue that may develop into stipular buds (Matthes et al. 2011). The stipular buds may originate new individuals as they form roots and sequentially start to produce leaves in the apical region of the new rhizome.

The occurrence of stipular buds in representatives of the family Marattiaceae has been reported by different authors. Sharpe \& Jernstedt (1991) observed such structures in individuals of Danaea wendlandii Reichenb. kept in a greenhouse in the United States, after obtaining them from the natural environment in Costa Rica. Chiou et al. (2006), obtained stipular buds from subterranean parts of the rhizome of natural populations of Archangiopteris somai Hayata and A. itoi (W.C.Shieh) J.M. Camus in Taiwan, and observed the formation of stipular buds after the third month of culture in the laboratory. Huang et al. (2010) found the emergence of stipular buds in five species of Marattiaceae native to Taiwan, one month after being subjected to different treatments in the laboratory. Matthes et al. (2011) performed experiments demonstrating that stipules of Angiopteris evecta (G.Forst.) Hoffm.. when placed in contact with soil, developed new leaves around six months after the start of culture. With exception of MacVeigh (1937), who reported the formation of stipular buds in A. evecta and Marratia alata Sw. (sin. Eupodium laeve (Sm.) Murdock) in natural populations, in all other studies listed, the stipular buds were found only under artificial survival conditions.

Danaea nodosa (L.) Sm. has wide occurrence in Brazil, with records for all regions of the country, where it has been observed in areas of cerrado (lato sensu) (Brazilian savanna) and pluvial forests (Prado et al. 2015). The distribution range of this species includes the Greater Antilles and Paraguay (Christenhusz 2010). The present study was conducted in the central region of the state of Mato Grosso do Sul, at municipality of Aquiduana ( $\left.20^{\circ} 27^{\prime} 23.6^{\prime \prime} \mathrm{S}, 55^{\circ} 30^{\prime} 01.0^{\prime \prime} \mathrm{W}\right)$, with a mean altitude of 170 to $180 \mathrm{~m}$. The climate of the region is defined as tropical savanna (Aw), with six to eight rainy months, dry winters and mean monthly temperature of about $25^{\circ} \mathrm{C}$ (Peel et al. 2007). The local vegetation is defined as gallery forest (Ribeiro \& Walter 2008).

During an ecological study (Jun/2006 to $\mathrm{Jul} / 2007$ ) involving a population of Danaea nodosa, the occurrence of buds originating from stipules was observed in individuals growing under natural conditions. The formation of stipular buds was observed in Aug and Sep/2006, end of the dry season. Thirteen individuals showed stipular buds $(30 \%$ of the individuals monitored during the ecological study), but only in two cases the development of ramets was observed (designated here individuals 1 and 2). In individual 1, 11 stipular buds were observed, of which only one (ramet 1) showed development that resulted in the formation of new leaves (Figure 1a and $1 b$ ). In individual 2, two stipular buds were observed, of which only one (ramet 2) resulted in the formation of new leaves (Figure 1c). The number of leaves and pinnae found in each ramet is presented in Table 1. In the following months (from Oct/2006) up to the end of the field observations (Jul/2007), there was no formation of new leaves on these two ramets.

In Apr/2008, the population studied was again visited for additional measurements and monitoring of the development of the ramets. Was observed that after the 2007/2008 rainy season, the ramets continued to produce new leaves, with the ramet 1 presenting 5 leaves and $9.3 \mathrm{~cm}$ the total length of the rhizome and the ramet 2 presenting 6 leaves and rhizome with $10.5 \mathrm{~cm}$ of lenght.

In Nov/2006, during the rainy season, a large tree had fallen in the study area, exposing part of the population (four individuals not previously monitored) to full sunlight. These individuals lost their leaves in the course of a month of observation, and between Nov/2006 and Jan/2007, we observed that the edge of the stipules acquired a greenish coloration, giving signs of meristematic activity. Between Mar and Apr/2007, we noted the formation of the first stipular buds. In one of these individuals, we counted 21 stipular buds (May/2007), of which none resulted in the formation of ramets with consequent production of leaves and/or roots. In Mar/2008 (more than a year with exposure to sunlight), we found that these stipular buds did not give rise to ramets with consequent production of fronds, although there were signs of meristematic 
activity. While a sudden disturbance may result in changes in growth patterns (Walker \& Sharpe 2010) such as the stipular meristematic activity we observed, development of roots and leaves may require special conditions to the environment of this naturally shade-tolerant fern.

Production of stipular buds appears to represent a response of individuals when subjected to different conditions of stress. The individuals where the formation of stipular buds was found were situated in the quadrants with low density $\left(0.22\right.$ individuals $/ \mathrm{m}^{2}$ - individual 1 ; and 0.44 individuals $/ \mathrm{m}^{2}$ - individual 2), occupying a peripheral position in the population studied, and they were exposed to full sunlight.
Studies with different species have demonstrated that generally there is greater investment effort in vegetative reproduction in individuals that are in conditions of lower density (Holler \& Abrahamson 1977; Obeso 2002). Sporophytes originating from vegetative reproduction allow the more rapid colonization of available environments, as noted by Sharpe \& Mehltreter (2010) and observed by different authors for other species of ferns (Walker 1966; Schmitt \& Windisch 2006). In Marattiaceae, gametophytes generally tend to grow slowly (Chou et al. 2007), which emphasizes the importance of vegetative reproduction in allowing these new plants to integrate rapidly with the
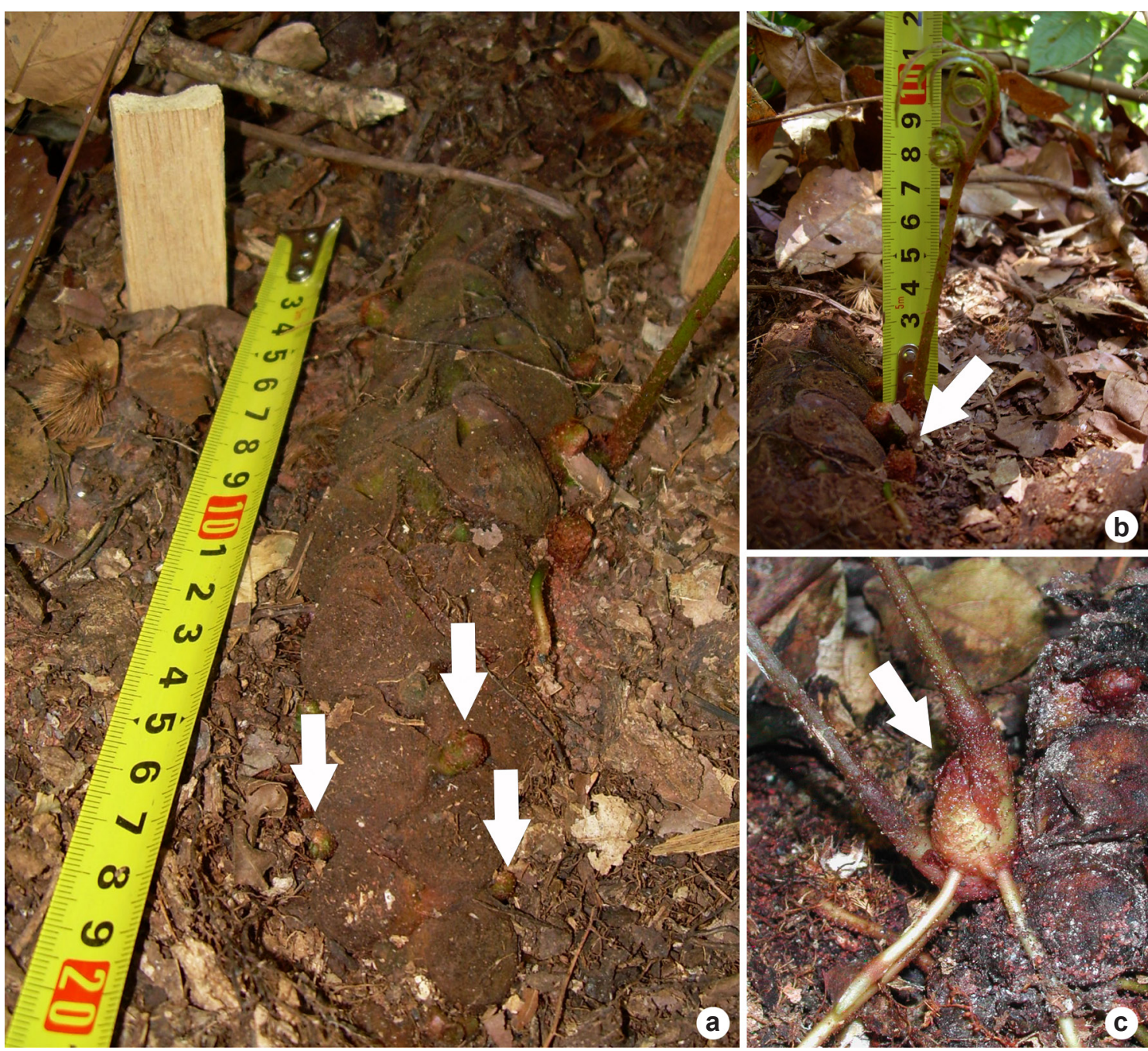

Figure 1 - Danaea nodosa into a gallery forest in Brazilian Savanna in September/2006 - a. formation of stipular buds in individual 1; b. stipular bud with formation of ramet (ramet 1); c. stipular bud with formation of ramet (ramet 2). Photos: Carlos Rodrigo Lehn. 
Table 1 - Number of leaves and pinnae per ramet formed in a population of Danaea nodosa situated in the CentralWest region of Brazil.

\begin{tabular}{lcccccccc}
\hline & \multicolumn{3}{c}{ Ramet 1 } & & \multicolumn{3}{c}{ Ramet 2 } \\
\cline { 2 - 3 } Leaves - Month & Length & $\begin{array}{c}\text { Number of } \\
\text { pinnae }\end{array}$ & $\begin{array}{c}\text { Total length } \\
\text { of ramet }\end{array}$ & & Length & $\begin{array}{c}\text { Number of } \\
\text { pinnae }\end{array}$ & $\begin{array}{c}\text { Total length } \\
\text { of ramet }\end{array}$ \\
\hline $1^{\text {st }}$ leaf - Aug $/ 2006$ & $5 \mathrm{~cm}$ & $5 \beta$ & & & $5 \mathrm{~cm}$ & 3 & \\
$2^{\text {nd }}$ leaf - Aug $/ 2006$ & $17 \mathrm{~cm}$ & 7 & $3 \mathrm{~cm}$ & & $21 \mathrm{~cm}$ & 5 & $8 \mathrm{~cm}$ \\
$3^{\text {rd }}$ leaf $-\mathrm{Sep} / 2006$ & - & - & & & $48 \mathrm{~cm}$ & 7 & \\
\hline
\end{tabular}

herbaceous stratum and thereby contribute to the maintenance of the species in the location. In addition, the form of creeping growth (as shown by D. nodosa) also provides greater efficiency in the occupation of the space (Senna \& Waechter 1997).

The few records about the formation of stipular buds under natural conditions should indicate the presence of mechanisms that inhibit their production in Marattiaceae, as reported by Sharpe \& Jernstedt (1991) and Huang et al. (2010). Widely used in horticulture, obtaining sporophytes through vegetative reproduction has been characterized as an efficient strategy for ex-situ conservation practices, where it can consequently contribute to increasing the success of programs aimed at the reintroduction of species in natural environments.

The present study, far from being conclusive, points out the importance understanding the ecology of species, which can help in establishing programs that can effectively help in conservation, especially with regard to rare and threatened species.

\section{Acknowledgments}

The authors thank to Post-graduation Program in Plant Biology - Federal University of Mato Grosso do Sul, for the logistical support in conducting the present study; Sociedade Batista de Mato Grosso do Sul, for allowing access to the study area; Caroline Leuchtenberger, Flávio Macedo Ales, Karina Rébulla, Franciele Maragno and Leopoldo Telles Neto kindly helped during the fieldwork; and CAPES for the Master's scholarship awarded to the first author. Dr. A. Leyva helped with English translation and editing of the manuscript; Dr. Joanne M. Sharpe and the anonymous reviewers kindly reviewed the manuscript giving valuable suggestions for the final version

\section{References}

Chiou WL, Huang YM \& Chen CM (2006) Conservation of two endangered ferns, Archangiopteris somai and A. itoi (Marattiaceae: Pteridophyta), by propagation from stipules. Fern Gazzette 17: 271-278.

Chou HM, Huang YM, Hsu SY \& Chiou WL (2007) Observations on gametophytes and juvenile sporophytes of Archangiopteris somai Hayata (Marattiaceae), an endangered fern in Taiwan. Botanical Studies 48: 205-213.

Christenhusz M (2010) Danaea (Marattiaceae) revisited: biodiversity, a new classification and ten new species of a neotropical fern genus. Botanical Journal of the Linnean Society 163: 360-385.

Holler L \& Abrahamson WG (1977) Seed and vegetative reproduction in relation to density in Fragaria virginiana (Rosaceae). American Journal of Botany 68: 1003-1007.

Huang YM, Huang MH, Chen CM \& Chiou WL (2010) Stipule propagation in five Marattioid species native to Taiwan (Marattiaceae; Pteridophyte). In: Fernández H, Kumar A \& Revilla MA (eds.) Working with ferns: issues and applications. Springer, New York. Pp. 127-134.

Matthes LAF, Uzzo RP \& Carvalho AC (2011) Propagação vegetativa de samambaia gigante - Angiopteris evecta (G.Forst) Hoffm. Revista Brasileira de Horticulura 17: 25-28.

McVeigh I (1937) Vegetative reproduction of the fern sporophyte. The Botanical Review 3: 457-497.

Obeso JR (2002) The costs of reproduction in plants. New Phytologist 155: 321-348.

Peel MC, Finlayson BL \& McMahon TA (2007) Updated world map of the Koppen-Geiger climate classification. Hydrology and Earth System Sciences 11: 1633-1644.

Prado J, Sylvestre LS, Labiak P, Windisch PG, Salino A, Barros ICL, Hirai R, Almeida TE, Santiago ACP, Kieling-Rubio MA, Pereira AFN, Øllgaard B, Ramos CGV, Mickel JT, Dittrich VAO, Mynssen CM, Schwartsburd PB, Condack JPS \& Matos FB (2015) Diversity of ferns and lycophytes in Brazil. Rodriguésia 66: 1073-1083. 
Ribeiro JF \& Walter BMT (2008) As principais fitofisionomias do bioma Cerrado. In: Sano SM, Almeida SP \& Ribeiro JF (eds.) Cerrado: ecologia e flora. Editora Embrapa, Brasília. Pp. 151-212.

Schmitt JL \& Windisch PG (2006) Growth rates and age estimates of Alsophila setosa Kaulf. in Southern Brazil. American Fern Journal 96: 103-111.

Senna RM \& Waechter JL (1997) Pteridófitas de uma floresta com araucária. 1: Formas biológicas e padrões de distribuição geográfica. Iheringia Série Botânica, Porto Alegre 48: 41-58.

Sharpe JM \& Jernstedt JA (1991) Stipular bud development in Danaea wendlandii (Marattiaceae). American Fern Journal 81: 119-127.

Sharpe JM \& Mehltreter K (2010) Ecological insights from fern population dynamics. In: Mehltreter K, Walker LR \& Sharpe JM (eds.) Fern ecology. Cambridge Press, New York. Pp. 61-110.
Sheffield E (2008) Alternation of generations. In: Hanker TA \& Haufler C. (eds.) Biology and evolution of ferns and Lycophytes. Cambridge University Press, New York. Pp. 49-74.

Troop JE \& Mickel JT (1968) Petiolar shoots in the Dennstaedtioid and related ferns. American Fern Journal 58: 64-70.

Tryon RM \& Tryon AF (1982) Ferns and allied plants, with special reference to Tropical America. Springer-Verlag, New York. 857p.

Walker LR \& Sharpe JM (2010) Ferns, disturbance and succession. In: Mehltretr K, Walker LR \& Sharpe JM (eds.) Fern ecology. Cambridge Press, New York. Pp. 177-219.

Walker TG (1966) Apomixis and vegetative reproduction in ferns. In: Hawkes JA (ed.) Reproductive biology and taxonomy of vascular plants. Botanical Society of the British Isles Conference Reports 9: 152-161. 